\title{
Experimental Metabolic Acidosis: The Enzymatic Basis of Ammonia Production by the Dog Kidney*
}

\author{
Victor E. Pollak, $\dagger$ Hermann Mattenheimer, $\$$ Hendrina DeBruin, and \\ KarLa J. Wein MaN \\ (From the Departments of Medicine and Biochemistry, Presbyterian-St. Luke's Hospital, Re- \\ search and Educational Hospitals, and the Departments of Medicine and \\ Biochemistry, University of Illinois College of Medicine,
}

Chicago, Ill.)

Ammonia excretion by the kidney has long been known to increase when a constant acid load is given to healthy subjects. This was clearly delineated by Sartorius, Roemmelt, and Pitts (1), who reported that when healthy humans were given a constant amount of ammonium chloride daily, there was a gradual increase in the excretion of ammonia, accompanied by an increased excretion of protons, and by an adaptation that resulted in the conservation of sodium and potassium ions.

These experiments were preceded by those of Van Slyke and his co-workers (2), who had demonstrated that glutamine was extracted from the renal arterial blood of acidotic dogs in amounts sufficient to account for about $60 \%$ of the $\mathrm{NH}_{3}$ excreted by the kidneys-an observation recently confirmed and extended by the experiments of Pitts and his colleagues $(3,4)$. The infusion of a variety of amino acids into the acidotic dog has also been shown to increase the rate of excretion of ammonia (5-8), L-glutamine, L-asparagine, Land $\mathrm{D}$-alanine, and L-histidine being the most effective.

The nature of the metabolic pathways involved and the enzymes responsible for catalyzing the relevant reactions are not yet clearly understood.

* Submitted for publication July 7, 1964 ; accepted October 8, 1964.

Supported by U. S. Public Health Service grant HE 3912 and by the Surgeon General's Office, U. S. Army, contract DA-49-007-MD-637.

† Work done during the tenure of an Established Investigatorship of the American Heart Association supported by the Chicago and Illinois Heart Associations. Presently Career Development awardee, U. S. Public Health Service grant 1-K3-HE-22,492-01.

$\ddagger$ Career Development awardee, U. S. Public Health Service grant 5-K3-GM-15,1524.
Davies and Yudkin were the first to demonstrate an adaptive increase in glutaminase activity in kidney slices from rats made chronically acidotic by the ingestion of $\mathrm{HCl}$ in their drinking water (9). Rector, Seldin, and Copenhaver observed a concordant relationship between glutaminase activity in homogenates of rat kidney and the increase in ammonia excretion during successive days of ammonium chloride administration (10). On the other hand, an increase in glutaminase activity occurred in both experimental acidosis and alkalosis in the guinea pig (11), and glutaminase activity did not appear to increase in the acidotic $\operatorname{dog}(12)$.

The present experiments were designed 1) to investigate the influence of ammonium chlorideinduced acidosis on the activity of enzymes catalyzing ammonia metabolism and the production and excretion of hydrogen ions, and on representative enzymes of glycolysis and the citric acid cycle in the kidney and liver of the dog; and 2) to attempt to relate quantitatively enzyme activity in the kidney to the ammonia production and hydrogen ion excretion by the kidney. The activity of most enzymes was studied quantitatively by ultramicrobiochemical techniques in the anatomical units of the nephron, individually dissected from frozen-dried $16-\mu$ sections; others were studied in homogenates. Enzyme activity in the liver was studied in homogenates.

\section{Methods}

Selection of dogs for study. That there is a high incidence of interstitial nephritis in dogs is well known (13), and in our experience interstitial nephritis is common in kidneys obtained from unselected dogs. The five male mongrel dogs used in these experiments were selected because they had good renal function. After de- 
hydration for 20 hours the urine specific gravity was 1.036 to 1.060 , the urine osmolality 1,442 to $2,188 \mathrm{mOsm}$ per $\mathrm{kg}$. There were no significant abnormalities on microscopic examination of the urine sediment. The serum creatinine levels varied from 0.67 to $0.79 \mathrm{mg}$ per 100 $\mathrm{ml}$ and the urea nitrogen levels from 7.5 to $22 \mathrm{mg}$ per $100 \mathrm{ml}$. The weights of the dogs chosen ranged from 10.2 to $15.7 \mathrm{~kg}$.

Design of the experiment. One dog was chosen at random as a control; the other four were designated the experimental animals. The dogs were kept in individual metabolic cages throughout the experiment. They were allowed water ad libitum and were fed a constant diet of Purina dog meal, horsemeat and gravy, and puppy kibbles mixed in the ratio $2: 1: 1$. The dogs ate approximately $450 \mathrm{~g}$ of this mixture daily, containing about $97 \mathrm{~g}$ of protein, $157 \mathrm{~g}$ of carbohydrate, and $26 \mathrm{~g}$ of fat. The control dog was pair-fed the average food intake of the four experimental dogs on the preceding day.

Twenty-four-hour urine collections were made using toluene and thymol crystals as preservatives. Feces were removed promptly from the cages to prevent contamination of the urine. Immediate analyses were made of urine volume, $\mathrm{pH}, \mathrm{NH}_{3}$, and bicarbonate; portions of the remaining urine were frozen for subsequent chemical analysis. Preliminary experiments were done in which dog urine samples, collected in identical manner with toluene and thymol, were stored for 24 to 36 hours at room temperature. Under these conditions, the $\mathrm{pH}, \mathrm{NH}_{\mathbf{s}}$, titratable acid, and bicarbonate concentrations did not change.

Each dog was studied during a 7-day control period. At the end of this period needle and wedge biopsies of the kidney and liver were taken transperitoneally under pentobarbital anesthesia. The dogs were allowed 1 week to recover from the operation and were then studied during a 7-day experimental period in which they received ammonium chloride, $112 \mathrm{mEq}$ daily in gelatin capsules in three divided doses. The control dog did not receive ammonium chloride, but was pair-fed and studied in an identical manner. At the end of the experimental period needle and wedge biopsies of kidney and liver were again taken transperitoneally under identical conditions. The kidney tissue of all five dogs was normal on histologic examination.

Handling of the renal biopsy specimens. Part of each biopsy specimen was frozen immediately in liquid nitrogen and prepared for analysis of enzyme activity as described previously (14). The methods of identifying and dissecting out the individual anatomical units of the nephron, with the stained section as control, and of weighing the tissue fragments on quartz fiber balances have been published $(14,15)$. For each enzyme studied, save for glutaminase, the two kidney specimens from a single dog were analyzed in a single experiment on the same day.

TABLE I

Optimal conditions for the assay of enzyme activities in the dog kidney*

\begin{tabular}{|c|c|c|c|c|c|c|}
\hline \multirow[b]{2}{*}{ Enzyme } & \multirow[b]{2}{*}{ Buffer } & \multirow[b]{2}{*}{ Substrate } & \multirow[b]{2}{*}{ Cofactor } & \multirow[b]{2}{*}{ Other } & \multicolumn{2}{|c|}{ Incubation product } \\
\hline & & & & & Volume & Measured \\
\hline LDH & $\begin{array}{c}M \\
\text { Tris, } 0.2 \\
\text { pH } 7.15\end{array}$ & $\begin{array}{c}m M \\
\text { Na-pyruvate, } 1.0\end{array}$ & $\mathrm{NADH}_{2}, 1.25 \mathrm{mM}$ & Nicotinamide, $25 \mathrm{mM}$ & $\begin{array}{l}\mu l \\
10\end{array}$ & NAD† \\
\hline MDH & $\begin{array}{c}\text { Tris, } 0.18 \\
\text { pH } 8.6\end{array}$ & Oxaloacetate, 1.1 & $\mathrm{NADH}_{2}, 1.30 \mathrm{mM}$ & Nicotinamide, $20 \mathrm{mM}$ & 10 & NAD \\
\hline GDH & $\begin{array}{c}\text { Tris, } 0.10 \\
\text { pH } 7.4\end{array}$ & $\begin{array}{l}\text { 2-Oxoglutarate, } 2.5 \\
\left(\mathrm{NH}_{4}\right)_{2} \mathrm{SO}_{4}, 75\end{array}$ & $\mathrm{NADH}_{2}, 2.8 \mathrm{mM}$ & Nicotinamide, $20 \mathrm{mM}$ & 2 & NAD \\
\hline \multirow[t]{2}{*}{ AspAT } & Tris, 0.10 & L-Aspartate, 48 & & $\mathrm{NADH}_{2}, 2.7 \mathrm{mM}$ & 5 & NAD \\
\hline & & 2-Oxoglutarate, 10 & & $\begin{array}{l}\text { MDH } \\
\text { Nicotinamide, } 20 \mathrm{mM}\end{array}$ & & \\
\hline \multirow[t]{2}{*}{ AlAT } & Tris, 0.15 & 2-Oxoglutarate, 10 & Pyridoxalphosphate, & $\mathrm{NADH}_{2}, 2.1 \mathrm{mM}$ & 5 & NAD \\
\hline & & L-Alanine, 43 & & $\begin{array}{l}\text { LDH } \\
\text { Nicotinamide, } 20 \mathrm{mM}\end{array}$ & & \\
\hline DAO & $\begin{array}{r}\text { Tris, } 0.07 \\
\text { pH } 7.8\end{array}$ & D-Alanine, 2.5 & FAD, $7.8 \times 10^{-6} \mathrm{M}$ & $\begin{array}{l}\mathrm{NADH}_{2}, 0.3 \mathrm{mM} \\
\mathrm{LDH}\end{array}$ & 210 & $\mathrm{NADH}_{2} \ddagger$ \\
\hline CS & $\begin{array}{r}\text { Tris, } 0.05 \\
\text { pH } 8.7\end{array}$ & Acetyl-S-CoA, 0.7 & & $\begin{array}{l}\text { K-malate, } 6.0 \mathrm{mM} \\
\text { NAD, } 0.9 \mathrm{mM} \\
\text { MDH }\end{array}$ & 160 & $\mathrm{NADH}_{2}$ \\
\hline Glutaminase I & $\begin{array}{c}\text { Tris, } 0.04 \\
\text { pH } 9.0\end{array}$ & L-Glutamine, 48 & & Phosphate, $0.2 \mathrm{M}$ & 25 & $\mathrm{NH}_{3} 8$ \\
\hline Glutaminase II & $\begin{array}{l}\text { Tris, } 0.04 \\
\text { pH } 8.75\end{array}$ & L-Glutamine, 48 & Pyruvate, $0.1 \mathrm{M}$ & 1 & 25 & $\mathrm{NH}_{3}$ \\
\hline $\begin{array}{l}\text { Glutaminase } \\
\text { nonactivated }\end{array}$ & $\begin{array}{l}\text { Tris, } 0.04 \\
\text { pH 8.75 }\end{array}$ & L-Glutamine, 48 & & & 25 & $\mathrm{NH}_{\mathbf{8}}$ \\
\hline
\end{tabular}

* LDH, MDH, and GDH = lactate, malate, and glutamate dehydrogenase; AspAT and AlAT = aspartate and alanine aminotransferase $\mathrm{DAO}=\mathrm{D}$-alanine oxidase $\mathrm{CS}=$ citrate synthase $; \mathrm{FAD}=$ flavin-adenine dinucleotide.

$\dagger$ Measured by fluorometry.

$\ddagger$ Measured by spectrophotometry.

Measured by diffusion and titration. 
A second part of each renal biopsy specimen, consisting of a wedge of cortex, was used for preparing tissue homogenate in ice cold distilled water using a PotterElvehjem all glass homogenizer. The liver biopsy specimen was handled similarly. A small portion (100 to 200 $\mathrm{mg}$ ) was cut from each specimen and was used to determine dry weight by drying at $110^{\circ} \mathrm{C}$ until the weight was constant.

Measurement of enzyme activity. Full details of the methods used to measure lactate dehydrogenase activity (16), carbonic anhydrase activity (17), glutaminase I and II activities (18), and the activity of the other enzymes examined (19) have been published. The optimal conditions, determined for the dog kidney (19), are summarized in Table I. In previous publications we have expressed enzyme activity in moles of substrate metabolized per kilogram dry tissue per hour $(\mathrm{MKH})$. To comply with the suggestions of the Commission on Enzymes of the International Union of Biochemistry, the results in this paper are expressed in micromoles per gram dry tissue per minute $(1 \mathrm{MKH}=16.6 \mu$ moles per $g$ per minute).

Nomenclature of enzymes. The nomenclature for enzymes as suggested in the Report of the Commission on Enzymes (20) is used in this paper. The classification number is given in brackets after the systematic name, and the suggested common name is in parentheses together with the abbreviation: D-aminoacid: $\mathrm{O}_{2}$ oxidoreductase [1.4.3.3] (D-aminoacid-oxidase, with D-alanine as substrate D-alanine-oxidase, DAO) ; citrate oxaloacetatelyase [4.1.37] (citrate synthase, CS); L-lactate: NAD oxidoreductase [1.1.1.27] (lactate dehydrogenase, LDH) ; L-malate: NAD oxidoreductase [1.1.1.37] (malate dehydrogenase, $\mathrm{MDH}$ ) ; L-glutamate: NAD oxidoreductase [1.4.1.2] (glutamate dehydrogenase, $\mathrm{GDH}$ ) ; L-alanine: 2-oxoglutarate aminotransferase [2.6.1.2] (alanine aminotransferase, AlAT) ; 1 L-aspartate : 2-oxoglutarate aminotransferase [2.6.1.1] (aspartate aminotransferase, AspAT) $;^{1}$ carbonate hydrolyase [4.2.1.1] (carbonic anhydrase, CA) ; and L-glutamine-aminohydrolyase [3.5.1.2] (glutaminase, Glut.).

Statistical analysis. The activity of each enzyme was analyzed in each renal structure independently. The design model for the analysis of variance was: $Y_{1 j k}=\mu+$ $T_{1}+D_{1}+\left(T \times D_{1 j}\right)+e_{k(1 j)}$, where $Y_{1 j k}=$ observed response of the $k^{\text {th }}$ determination of the $j^{\text {th }}$ dog receiving $\mathrm{i}^{\text {th }}$ treatment ; $\mu=$ general mean; $T_{1}=$ treatment effect due to the $i^{\text {th }}$ treatment; $D_{j}=$ effect attributable to $\operatorname{dog} j$; $T \times D_{i j}=$ interaction effect of the $i^{\text {th }}$ treatment on the $j^{\text {th }}$ dog; $\mathbf{e}_{\mathbf{k}(1 \mathrm{j})}=$ effect attributable to the $\mathbf{k}^{\text {th }}$ determination made on $\operatorname{dog} j$ treated with treatment $i$. The mean square estimators in the analysis of variance are:
Source of variation

Between dogs

Between treatments

Treatment $X$ dog interaction

Determinations within treatment within dog

Total

$$
\begin{gathered}
\text { Degrees of freedom } \\
d-1 \\
t-1 \\
(t-1)(d-1) \\
\Sigma\left(n_{k}-1\right) \\
N-1
\end{gathered}
$$

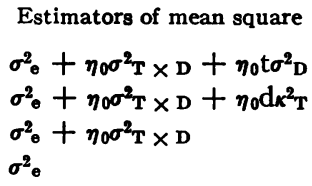

where

$$
\eta_{0}=1 /(\mathrm{dt}-1) \times\left(\Sigma \eta_{\mathrm{ij}}-\Sigma \eta_{\mathrm{ij}}^{2} / \Sigma \eta_{\mathrm{ij}}\right)
$$

The design is balanced in respect to dogs and treatments, but not necessarily in respect to the number of determinations made on each structure of each biopsy within each dog.

When the $F$ ratio of treatment $\times$ dog interaction was significant at the $5 \%$ probability level, the interaction mean square was used as the error term for testing the significance of differences between treatments; when this interaction was not significant, a pooled error term was used.

Differences in treatments might be due to the effect of the ammonium chloride administration itself or to one or more of the effects of time and of the surgical trauma associated with the biopsy or to all of these. To estimate the effects of surgical trauma and time, independent of treatment, the single control dog was analyzed for differences between biopsies. It is desirable to use more dogs as controls, but the volume of the enzyme analyses involved precluded this.

\section{Results}

\section{Metabolic studies}

The dogs were in good health throughout the study, did not vomit, and did not lose weight during the period of ammonium chloride administration. The dogs had not been trained, and the urine

1 The report did not include suggestions for abbreviations for enzymes. Although the abbreviations used hitherto for most enzymes are still meaningful, some abbreviations must be changed. Thus for two enzymes included in this study, new abbreviations are introduced in accordance with new systematic and common names: a) alanine-amino transferase, hitherto known as glutamate-pyruvate-transaminase (GPT), is now abbreviated $\mathrm{AlAT}$, and $b$ ) aspartate-amino transferase, hitherto known as glutamate-oxalacetate-transaminase (GOT), is now abbreviated AspAT. 
volumes obtained, although complete, were not true 24-hour collections. Thus there was a large variation in the day-to-day urine volumes and in the daily excretion of the substances measured. Nevertheless the basic trends are clear as summarized in Figures 1 and 2, in which the average values for the four experimental dogs are plotted in solid lines, the values for the single control dog in broken lines. In the control period the urine $\mathrm{pH}$ and the daily excretion of titratable acid, $\mathrm{NH}_{3}$, hydrogen ion, sodium, potassium, chloride, and phosphate were of similar magnitude in the experimental and control dogs. With ammonium chloride loading the urine $\mathrm{pH}$ fell promptly from an average of 6.85 to 5.89 on the first day and

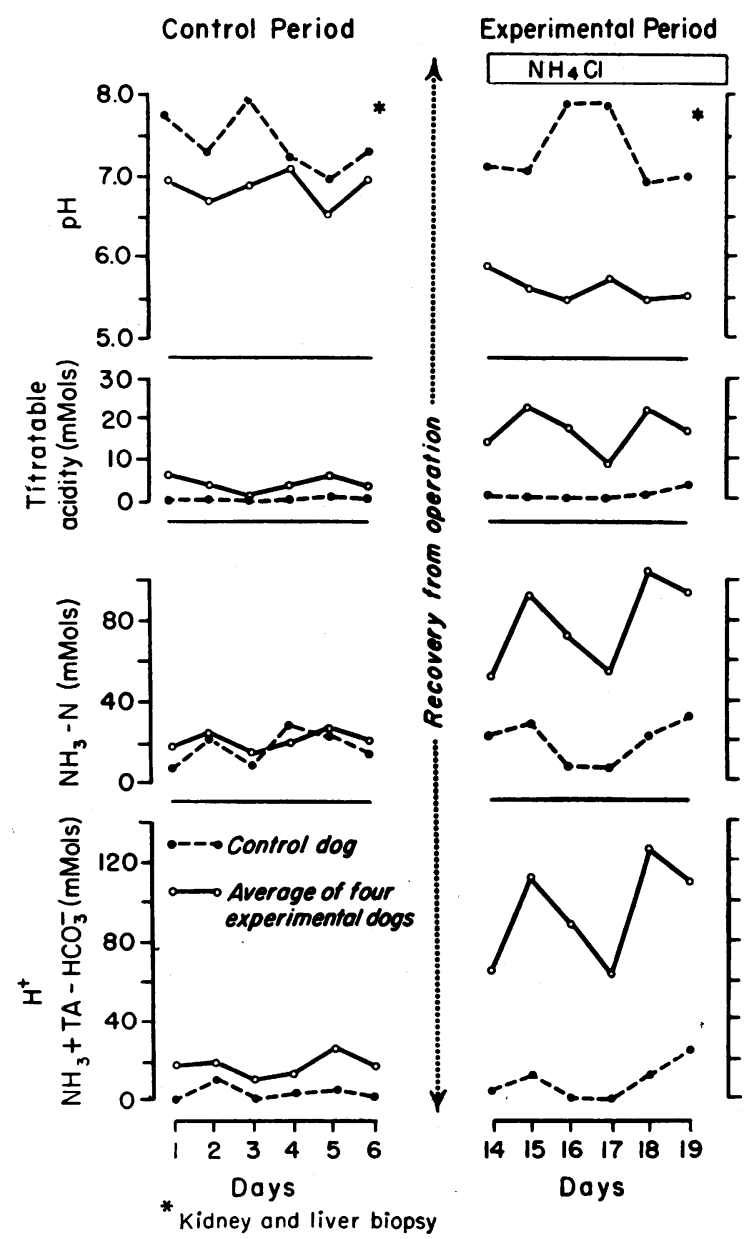

Fig. 1. URINe PH AND 24-Hour titratable aCID, AMMONIA, AND TOTAL HYDROGEN ION EXCRETION BEFORE AND DURING THE DAILY ADMINISTRATION OF $112 \mathrm{ME} Q$ OF AMMONIUM CHLORIDE.

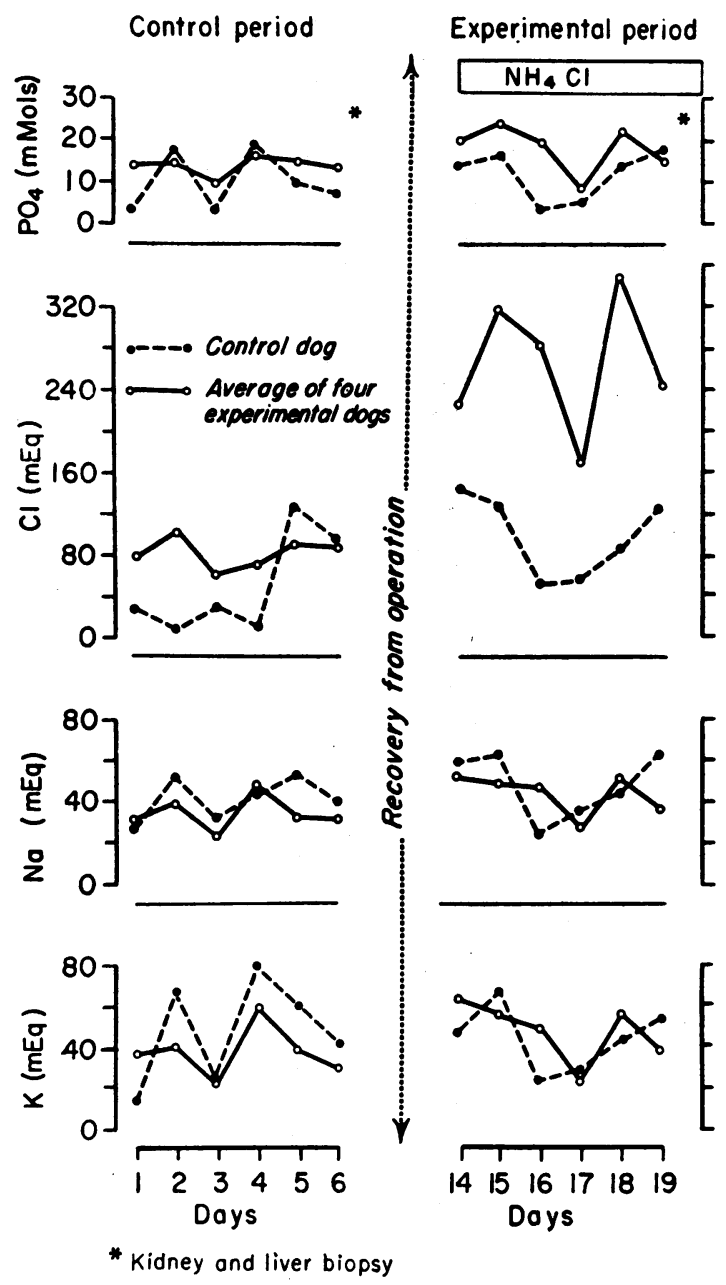

Fig. 2. TWENTY-FOUR-HOUR URINE CHLORIDE, INORGANIC PHOSPHATE, SODIUM, AND POTASSIUM EXCRETION BEFORE AND DURING THE DAILY ADMINISTRATION OF 112 ME $Q$ OF AMMONIUM CHLORIDE.

varied thereafter from 5.47 to 5.73 . The excretion of titratable acid increased from an average of 3.6 mmoles to 17.4 mmoles per day, of ammonia from 20 to 78 mmoles per day, and of net $\mathrm{H}^{+}$excretion $\left(\mathrm{TA}+\mathrm{NH}_{3}{ }^{+}-\mathrm{HCO}_{3}{ }^{-}\right)$from 16 to 93.5 mmoles per day. There was a significant relation$\operatorname{ship}(\mathrm{r}=-0.65, \mathrm{p}<0.001)$ between $\mathrm{pH}$ and the logarithm of $\mathrm{NH}_{3}$ excretion in the control period but no relationship $(r=-0.17,0.50>p>0.40)$ in the experimental period. The excretion of sodium and potassium did not change significantly at the beginning of or throughout the period of ammonium chloride loading.

The plasma bicarbonate levels were not meas- 
TABLE II

The effect of ammonium chloride administration on enzyme activities in the nephron of the dog*

\begin{tabular}{|c|c|c|c|c|c|c|}
\hline \multirow[b]{3}{*}{ Structure } & \multirow{3}{*}{$\begin{array}{l}\text { No. } \\
\text { of } \\
\text { dogs }\end{array}$} & \multirow{3}{*}{$\begin{array}{l}\text { Average } \\
\text { no. of } \\
\text { determi- } \\
\text { nations } \\
\text { per } \\
\text { biopsy }\end{array}$} & \multicolumn{4}{|c|}{ Enzyme activity } \\
\hline & & & \multicolumn{2}{|c|}{ Normal metabolic conditions } & \multicolumn{2}{|c|}{ During $\mathrm{NH}_{4} \mathrm{Cl}$ administration } \\
\hline & & & Mean & Range & $\begin{array}{c}\text { Mean } \\
\text { change }\end{array}$ & $\begin{array}{l}95 \% \text { confidence limits } \\
\text { of mean change }\end{array}$ \\
\hline & & & \multicolumn{4}{|c|}{ 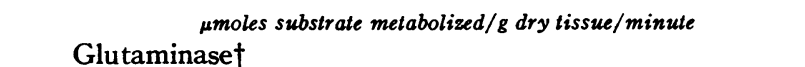 } \\
\hline Cortical homogenate & 4 & 3.6 & 18.6 & $16.0-21.5$ & -3.4 & $(-10.4$ and +3.7$)$ \\
\hline \multicolumn{7}{|c|}{ D-Alanine oxidase $\ddagger$} \\
\hline \multicolumn{7}{|c|}{ Citrate synthase $\ddagger$} \\
\hline Cortical homogenate & 4 & 2.0 & 21.6 & $19.2-25.2$ & +0.8 & $(-4.0$ and +5.5$)$ \\
\hline \multicolumn{7}{|c|}{ Glutamate dehydrogenase $\S$} \\
\hline $\begin{array}{l}\text { Glomeruli } \\
\text { Proximal convolutions } \\
\text { Distal convolutions }\end{array}$ & $\begin{array}{l}3 \\
3 \\
3\end{array}$ & $\begin{array}{l}4.8 \\
9.8 \\
9.8\end{array}$ & $\begin{array}{l}13.6 \\
73.8 \\
84.7\end{array}$ & $\begin{array}{l}9.7-15.8 \\
62.8-87.5 \\
64.7-110\end{array}$ & $\begin{array}{r}+2.8 \\
+6.4 \\
+11.6\end{array}$ & $\begin{array}{l}(-10.0 \text { and }+15.6) \\
(-37.8 \text { and }+50.6) \\
(-323 \text { and }+346)\end{array}$ \\
\hline \multicolumn{7}{|c|}{ Aspartate aminotransferase $\S$} \\
\hline $\begin{array}{l}\text { Glomeruli } \\
\text { Proximal convolutions } \\
\text { Distal convolutions } \\
\text { Medullary rays }\end{array}$ & $\begin{array}{l}4 \\
4 \\
4 \\
2\end{array}$ & $\begin{array}{l}4.3 \\
7.6 \\
6.5 \\
4.5\end{array}$ & $\begin{array}{l}70.2 \\
199 \\
372 \\
188\end{array}$ & $\begin{array}{l}45.0-132 \\
158-235 \\
243-530 \\
138-250\end{array}$ & $\begin{array}{l}+53.7 \\
+98.9 \\
+115 \\
+100\end{array}$ & $\begin{array}{l}(-27.9 \text { and }+135) \\
(-14.8 \text { and }+213) \\
(-87.0 \text { and }+317) \\
(-15.4 \text { and }+215)\end{array}$ \\
\hline \multicolumn{7}{|c|}{ Alanine aminotransferase§ } \\
\hline $\begin{array}{l}\text { Glomeruli } \\
\text { Proximal convolutions } \\
\text { Distal convolutions } \\
\text { Medullary rays }\end{array}$ & $\begin{array}{l}3 \\
4 \\
4 \\
2\end{array}$ & $\begin{array}{l}4.1 \\
7.5 \\
7.7 \\
3.8\end{array}$ & $\begin{array}{l}12.2 \\
52.2 \\
44.3 \\
67.8\end{array}$ & $\begin{array}{r}4.8-21.6 \\
36.8-78.2 \\
29.2-68.3 \\
39.8-98.3\end{array}$ & $\begin{array}{r}-3.5 \\
-2.1 \\
+1.9 \\
+12.4\end{array}$ & $\begin{array}{l}(-15.6 \text { and }+8.7) \\
(-19.4 \text { and }+15.2) \\
(-31.1 \text { and }+34.9) \\
(-87.7 \text { and }+112)\end{array}$ \\
\hline
\end{tabular}

* The first assay was made at the end of a 7-day control period, the second at the end of a 7-day period of ammonium chloride administration, $112 \mathrm{mEq}$ daily.

† Glutaminase I activity was measured at $\mathrm{pH} 9.5$ at $37^{\circ} \mathrm{C}$. The conditions for this assay, which were taken from the literature, were in fact suboptimal. Later, optimal conditions for glutaminase were reinvestigated (18), and the full study was repeated on two dogs (see text and Table III).

D-Alanine oxidase and citrate synthase activities were measured at $22^{\circ} \mathrm{C}$.

$\S \mathrm{GDH}$, AspAT, and AlAT activities were measured at $37^{\circ} \mathrm{C}$.

ured because of an error in the laboratory. When the second biopsy was taken, the average arterial $\mathrm{pH}$ of the four experimental dogs was 7.25, and the average serum chloride concentration was 112 mEq per L.

\section{Enzyme activity in the kidney}

Glutaminase. Glutaminase I activity (Table II) was measured in cortical homogenates according to optimal conditions described by Richterich and Goldstein (21). It could not be measured in the anatomical units of the nephron, as the enzyme activity is destroyed by freeze-drying (18). The average activity was $18.6 \mu$ moles per $g$ per minute. With ammonium chloride loading it decreased slightly in all four dogs; a decrease of similar magnitude was also observed in the control dog.
Subsequently, further studies were made of the optimal conditions for the assay of glutaminase activity (18), and we found that the conditions under which enzyme activity had been assayed were not in fact optimal. When new optimal conditions had been established, dogs 1 and 3 were restudied under metabolic conditions identical to those of the original experiment. The other three dogs were studied only under normal metabolic conditions. The results are given in Table III. Glutaminase I activity in the cortex was found to be $206 \mu$ moles per $g$ per minute, i.e., 11 times higher than in the original experiment. It did not change significantly with ammonium chloride administration. Glutaminase II activity was low, $19.8 \mu$ moles per $g$ per minute; it increased slightly in both dogs. Nonactivated glutaminase activity was low, $8.5 \mu$ moles per $g$ per minute, and in- 
TABLE III

Glutaminase I, glutaminase II, and nonactivated glutaminase activities in homogenates from canine kidney*

\begin{tabular}{|c|c|c|c|c|c|c|c|c|c|}
\hline \multirow[b]{2}{*}{ Enzyme } & \multirow[b]{2}{*}{ Structure } & \multicolumn{6}{|c|}{ Normal metabolic conditions } & \multicolumn{2}{|c|}{$\underset{\text { ministration }}{\operatorname{During} \mathrm{NH}_{4} \mathrm{Cl} \text { ad- }}$} \\
\hline & & Dog 1 & $\operatorname{Dog} 2$ & $\operatorname{Dog} 3$ & $\operatorname{Dog} 4$ & $\operatorname{Dog} 5$ & Average & Dog 1 & $\operatorname{Dog} 3$ \\
\hline Glutaminase I & $\begin{array}{l}\text { Cortex } \\
\text { Medulla }\end{array}$ & 230 & 170 & 222 & 188 & $\begin{array}{l}217 \\
100\end{array}$ & 206 & $\begin{array}{l}257 \\
95.8\end{array}$ & $\begin{array}{l}243 \\
84.7\end{array}$ \\
\hline Glutaminase II & $\begin{array}{l}\text { Cortex } \\
\text { Medulla }\end{array}$ & 19.7 & 19.7 & 22.2 & 17.3 & $\begin{array}{r}20.7 \\
9.3\end{array}$ & 19.8 & $\begin{array}{l}28.5 \\
17.7\end{array}$ & $\begin{array}{l}32.0 \\
17.7\end{array}$ \\
\hline $\begin{array}{l}\text { Nonactivated } \\
\text { glutaminase }\end{array}$ & $\begin{array}{l}\text { Cortex } \\
\text { Medulla }\end{array}$ & 9.0 & 7.2 & 8.5 & 8.0 & $\begin{array}{l}9.8 \\
4.3\end{array}$ & 8.5 & $\begin{array}{r}23.8 \\
9.8\end{array}$ & $\begin{array}{r}17.3 \\
9.0\end{array}$ \\
\hline
\end{tabular}

* The data are from second experiments in which the enzyme activities were assayed under the optimal conditions determined in our laboratory (18). The results are expressed as micromoles of ammonia formed per gram dry weight of tissue per minute at $37^{\circ} \mathrm{C}$.

creased twofold in the kidney homogenates of both dogs.

D-Alanine oxidase and citrate synthase. DAO and CS activities were measured in cortical homogenates only (Table II). DAO activity could not be measured in frozen-dried sections because the oxygen tension cannot yet be kept high enough to saturate the enzyme during 1-hour incubation in ultramicro test tubes. An ultramicro method for citrate synthase activity has not yet been developed. In cortical homogenates the average DAO and CS activities were 8.5 and $21.7 \mu$ moles per $g$ per minute, respectively, and did not change with ammonium chloride administration.

Glutamate dehydrogenase activity was measured in the control dog and in three experimental dogs (Table II). GDH activity was relatively low in the glomeruli (mean, $13.6 \mu$ moles per $\mathrm{g}$

TABLE IV

The effect of ammonium chloride administration on enzyme activities in the nephron of the $d$ og $^{*}$

\begin{tabular}{|c|c|c|c|c|c|c|}
\hline \multirow[b]{3}{*}{ Structure } & \multirow{3}{*}{$\begin{array}{l}\text { No. } \\
\text { of } \\
\text { dogs }\end{array}$} & \multirow{3}{*}{$\begin{array}{c}\text { Average } \\
\text { no. of } \\
\text { determi- } \\
\text { nations } \\
\text { per } \\
\text { biopsy }\end{array}$} & \multicolumn{4}{|c|}{ Enzyme activity } \\
\hline & & & \multicolumn{2}{|c|}{ Normal metabolic conditions } & \multicolumn{2}{|c|}{ During $\mathrm{NH}_{4} \mathrm{Cl}$ administration } \\
\hline & & & Mean & Range & Mean change & $\begin{array}{l}95 \% \text { confidence limits of } \\
\text { mean change }\end{array}$ \\
\hline & & & \multicolumn{4}{|c|}{ 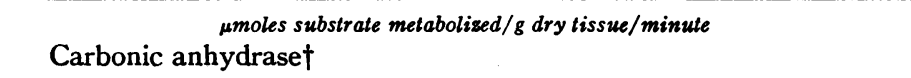 } \\
\hline $\begin{array}{l}\text { Glomeruli } \\
\text { Proximal convolutions } \\
\text { Distal convolutions } \\
\text { Medullary rays }\end{array}$ & $\begin{array}{l}4 \\
4 \\
4 \\
2\end{array}$ & $\begin{array}{r}5.4 \\
17.7 \\
14.5 \\
4.5\end{array}$ & $\begin{array}{l}106,500 \\
365,000 \\
354,700 \\
195,800\end{array}$ & $\begin{array}{r}94,800-120,000 \\
296,700-455,000 \\
189,500-513,300 \\
164,300-214,800\end{array}$ & $\begin{array}{r}-5,400 \\
+134,600 \\
-16,300 \\
+81,500\end{array}$ & $\begin{array}{l}(-62,900 \text { and }+52,200) \\
(-102,300 \text { and }+371,600) \\
(-870,600 \text { and }+930,200) \\
(-122,300 \text { and }+285,300)\end{array}$ \\
\hline \multicolumn{7}{|c|}{ Lactate dehydrogenase } \\
\hline $\begin{array}{l}\text { Glomeruli } \\
\text { Proximal convolutions } \\
\text { Distal convolutions } \\
\text { Medullary rays }\end{array}$ & $\begin{array}{l}2 \\
2 \\
2 \\
2\end{array}$ & $\begin{array}{l}4.8 \\
7.2 \\
7.0 \\
5.0\end{array}$ & $\begin{array}{r}694 \\
2,170 \\
2,345 \\
1,782\end{array}$ & $\begin{array}{c}645-743 \\
1,917-2,417 \\
1,850-2,917 \\
1,650-1,917\end{array}$ & $\begin{array}{r}-58 \\
+88 \\
+156 \\
+33\end{array}$ & $\begin{array}{l}(-468 \text { and }+352) \\
(-884 \text { and }+1,060) \\
(-1,548 \text { and }+1,859) \\
(-895 \text { and }+961)\end{array}$ \\
\hline \multicolumn{7}{|c|}{ Malate dehydrogenase $\S$} \\
\hline $\begin{array}{l}\text { Glomeruli } \\
\text { Proximal convolutions } \\
\text { Distal convolutions } \\
\text { Medullary rays }\end{array}$ & $\begin{array}{l}2 \\
2 \\
2 \\
1\end{array}$ & $\begin{array}{l}4.2 \\
7.2 \\
7.5 \\
5.0\end{array}$ & $\begin{array}{r}979 \\
3,154 \\
4,600 \\
2,917\end{array}$ & $\begin{array}{r}725-1,180 \\
2,800-3,550 \\
4,500-4,683\end{array}$ & $\begin{array}{l}+23.2 \\
+135 \\
+66.7 \\
-384\end{array}$ & $\begin{array}{l}(-424 \text { and }+470) \\
(-1,172 \text { and }+1,441) \\
(-2,711 \text { and }+2,845)\end{array}$ \\
\hline
\end{tabular}

* The first assay was made at the end of a 7-day control period, the second at the end of a 7-day period of ammonium chloride administration, $012 \mathrm{mEq}$ daily.

$\dagger$ Carbonic anhydrase activity was measured at $0^{\circ} \mathrm{C}$.

$\ddagger$ Lactate dehydrogenase activity was measured at $37^{\circ} \mathrm{C}$.

$\$$ Malate dehydrogenase activity was measured at $25^{\circ} \mathrm{C}$; the values given have been converted to activity at $37^{\circ} \mathrm{C}$ with the experimentally determined conversion factor, 2.30 . 
per minute), and there was no significant difference in activity in proximal and distal convolutions (mean, 73.8 and $84.7 \mu$ moles per $g$ per minute, respectively). There was no significant or consistent change in GDH activity with ammonium chloride loading.

Aspartate amino transferase activity (Table II). AspAT activity was lowest in the glomeruli (mean, $70.2 \mu$ moles per $g$ per minute) and was higher in the distal (mean, $372 \mu$ moles per $g$ per minute) than in the proximal convolutions (mean, $199 \mu$ moles per $g$ per minute). This difference was statistically significant $\left(\mathrm{F}_{24,30}=3.77, \mathrm{p}<\right.$ $0.001)$. There was no significant difference in AspAT activity in the first and second biopsies of the control dog. With ammonium chloride loading AspAT activity increased significantly in glomeruli $\left(F_{1,29}=7.79, p<0.01\right)$, proximal $\left(F_{1,58}\right.$ $=24.85, \mathrm{p}<0.001)$ and distal $\left(\mathrm{F}_{1,47}=8.49, \mathrm{p}<\right.$ $0.01)$ convolutions, and medullary rays $\left(F_{1,15}=\right.$ 15.17, $\mathrm{p}<0.01)$.

Alanine aminotransferase activity (Table II). The mean AlAT activity in the glomeruli was $12.2 \mu$ moles per $g$ per minute. The activity was slightly but not significantly higher in proximal (mean, $52.2 \mu$ moles per $\mathrm{g}$ per minute) than in distal convolutions (mean, $44.3 \mu$ moles per $g$ per minute). There was no significant change in AlAT activity with ammonium chloride administration.

Carbonic anhydrase activity (Table IV). The mean CA activity in the glomeruli was 106,500 $\mu$ moles per $g$ per minute at the end of the control period. The mean CA activity in the proximal and distal convolutions was 365,000 and 354,700 $\mu$ moles per $\mathrm{g}$ per minute, respectively. The activity was higher in the proximal convolutions of three dogs, in the distal convolutions of the other two. With ammonium chloride loading there was no change in CA activity in the glomeruli or distal convolutions; in the proximal convolutions the mean activity increased by $134,600 \mu$ moles per $g$ per minute. This increase appears to be significant $\left(F_{1,135}=17.68, p<0.001\right)$ but is interpreted with caution because the variance of the control and treatment data was different.

Lactate dehydrogenase activity (Table IV). As reported previously (16) LDH activity was lowest in the glomeruli; it was slightly but not significantly higher in the distal than in the prox-

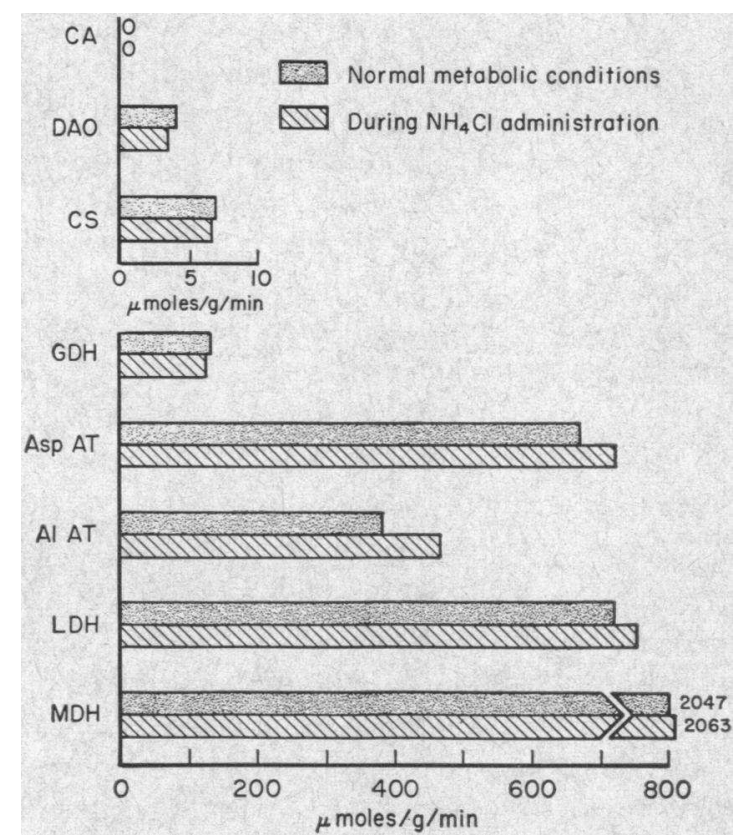

Fig. 3. ENZYME ACTIVITY IN HOMOGENATES OF BIOPSIES OF DOG LIVER BEFORE AND DURING THE DAILY ADMINISTRATION OF 112 MEQ OF AMMONIUM CHLORIDE. The activity is expressed in micromoles of substrate split per gram dry weight of tissue per minute at $37^{\circ} \mathrm{C}$. $\mathrm{CA}=$ carbonic anhydrase; $\mathrm{DAO}=\mathrm{D}$-alanine oxidase $\mathrm{CS}=$ citrate synthase; $\mathrm{GDH}, \mathrm{LDH}$, and $\mathrm{MDH}=$ glutamate, lactate, and malate dehydrogenase; AspAT and AlAT = aspartate and alanine aminotransferase.

imal convolutions. LDH activity was studied in only two experimental dogs and did not change with ammonium chloride loading.

Malate dehydrogenase activity (Table IV). The mean MDH activity in glomeruli was 979 $\mu$ moles per $\mathrm{g}$ per minute. The MDH activity was significantly higher $\left(F_{29,28}=4.49, p<0.001\right)$ in the distal (mean $4,600 \mu$ moles per $g$ per minute) than in the proximal convolutions (mean, 3,154 $\mu$ moles per $g$ per minute). No change in $\mathrm{MDH}$ activity occurred with ammonium chloride loading.

\section{Enzyme activity in the liver}

Glutaminase activity was not studied in liver homogenates, as the optimal conditions for assay in the dog liver differed from those for the kidney and had not been clearly defined when the experiment was done. The results of the assays for the activity of the other eight enzymes studied are summarized in Figure 3. No carbonic anhydrase activity could be detected in the liver. Alanine 
amino transferase activity increased slightly with ammonium chloride administration, but the difference was not significant $\left(F_{1,3}=6.74 ; 0.10>p\right.$ $>0.05)$. Aspartate amino transferase activity also increased slightly $\left(\mathrm{F}_{1,39}=7.15, \mathrm{p}<0.02\right)$, but in contrast with the findings in the kidney, the difference was very small and is probably not significant biologically. There was no change in activity of any of the other enzymes studied.

\section{Discussion}

The dogs studied in this experiment excreted an average of 20 mmoles of $\mathrm{NH}_{3}$ per day (i.e., $13.9 \mu$ moles per minute) under normal metabolic conditions; the excretion increased to 78 mmoles per day (i.e., $54.2 \mu$ moles per minute) in metabolic acidosis. The amount of $\mathrm{NH}_{3}$ added to the renal venous blood was not measured but was assumed to be 12 to $18 \mu$ moles per minute in metabolic acidosis $(2,4)$. Thus, the total $\mathrm{NH}_{3}$ production by the kidney in acidosis was about $70 \mu$ moles per minute. In the discussion that follows we attempt to explain on a quantitative basis the interrelationships between enzyme activity and $\mathrm{NH}_{3}$ production under both normal conditions and acidosis.

The role of glutaminase in ammonia production. In 1943 Van Slyke and his colleagues (2) showed that about $60 \%$ of the $\mathrm{NH}_{3}$ excreted by the kidneys of acidotic dogs could be accounted for by extraction of glutamine from the renal arterial blood. This finding has recently been confirmed by Pitts and his co-workers in the $\operatorname{dog}(3,4)$ and by Owen and Robinson in man (22). In the acidotic rat, in which glutamine extraction has not been determined, Davies and Yudkin (9) and Rector, Seldin, and Copenhaver (10) found that glutaminase activity increased pari passu with the increase in ammonia excretion. On the other hand Rector and Orloff (12) have demonstrated that glutaminase activity in the kidney of the acidotic dog was the same as that in the alkalotic animal. Although they did not study glutaminase activity in the normal dog, they concluded that phosphate- and pyruvate-activated glutaminase activity did not increase in metabolic acidosis in the dog. This conclusion was not completely justified, because it is not known whether glutaminase activity increases in metabolic alkalosis in the dog. In the guinea pig, the only animal so studied, glutaminase activity is increased in both alkalosis and acidosis (11). The fourfold increase in $\mathrm{NH}_{3}$ excretion in metabolic acidosis in the present experiments in the dog was not accompanied by any change in phosphate- and pyruvateactivated glutaminase activity.

After the optimal conditions for the in vitro assay had been finally determined in our laboratory, glutaminase I activity was found to be considerably higher than that reported previously (18). The optimal values for glutaminase activity are used in making the calculations which follow and which attempt to correlate the measured excretion and production of $\mathrm{NH}_{3}$ by the kidney with the measured glutaminase activity.

In vitro conditions differ considerably from in vivo intracellular conditions. Consequently, enzyme activity measured in vitro is unlikely to be the same as the in vivo activity. For no enzyme system are all the intracellular conditions known. In the case of glutaminase the concentration of substrate and cofactors in the kidney has been described. Thus, it is possible to attempt to calculate the activity in vivo. In making all such calculations we are fully aware that unknown factors could influence derived data on in vivo activity. The optimal glutamine concentration for the glutaminase I assay in vitro was $48 \mathrm{mM}$. This is much higher than the glutamine concentration of $1.38 \mu$ moles per $g$ wet weight in the dog kidney cortex in acidosis (3). As the water content of dog kidney cortex is about $77 \%$, the glutamine concentration is about 1.79 mmoles per L. Glutaminase I activity, determined in vitro at the in vivo glutamine concentration, was about $7.5 \%$ of the activity measured with the optimal in vitro glutamine concentration (18). The inorganic phosphate concentration, optimal in vitro at $0.2 \mathrm{M}$, is probably about 0.01 to $0.02 \mathrm{M}$ within the cell (23). The glutaminase I activity measured with $0.02 \mathrm{M}$ phosphate was $36 \%$ of that measured with $0.2 \mathrm{M}$ phosphate (18). Correcting for in vivo glutamine and phosphate concentrations would reduce the activity to $2.75 \%$ of the optimal in vitro activity. The $\mathrm{pH}$ optimum in vitro was 9.0 , considerably higher than the cellular $\mathrm{pH}$ of about 7.1 (24), although the $\mathrm{pH}$ at the intracellular site of action of glutaminase is unknown. At this $\mathrm{pH}$ glutaminase activity in vitro was about $40 \%$ of the activity at $\mathrm{pH} 9.0$ (18). Thus, 


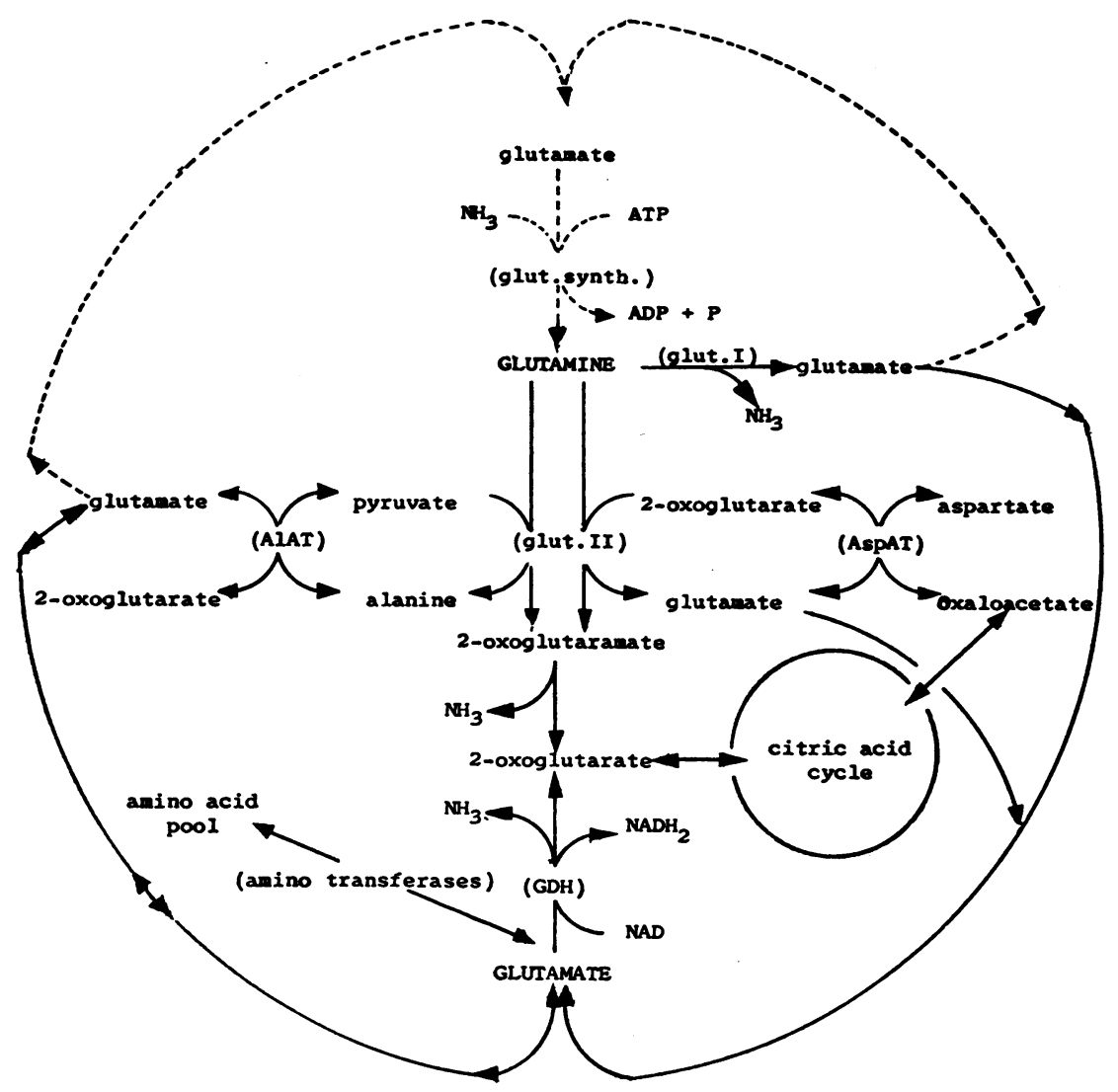

Fig. 4. INTERRELATIONSHIP OF THE REACTIONS INVOLVED IN AMMONIA METABOLISM IN THE KIDNEY. See text for detailed discussion. As there is doubt about the glutamine synthase activity in the dog kidney, the reactions involved are represented by a dotted line.

when we correct for glutamine and phosphate concentrations and for $\mathrm{pH}$, the in vivo glutaminase activity is $1.1 \%$ of the measured in vitro activity of $205 \mu$ moles per $g$ per minute in the cortex and $90 \mu$ moles per $g$ per minute in the medulla. If these derivations are valid, the phosphate-activated glutaminase of the kidney cortex would split 39.2 $\mu$ moles of glutamine per minute, freeing an equimolar amount of $\mathrm{NH}_{3} ;^{2}$ the glutaminase $\mathrm{I}$ of medulla and papilla would split only $3.3 \mu$ moles of glutamine per minute. The pyruvate-activated glutaminase of cortex, medulla, and papilla would split $4.4 \mu$ moles per minute under in vivo conditions. Thus, the total glutaminase activity of the two dog kidneys would be $46.9 \mu$ moles per minute. In the nonacidotic dogs this is 3.3 times the amount of $\mathrm{NH}_{3}$ excreted; in the acidotic dogs it

\footnotetext{
${ }^{2}$ Assuming that the two kidneys weigh $98 \mathrm{~g}$ (25); the dry weight of the kidneys was found to be $23 \%$.
}

is about $87 \%$ of the amount excreted and about $66 \%$ of the amount produced.

If these derivations are valid, the glutaminase activity present in the normal dog kidney has the capacity to split from glutamine the increased amount of $\mathrm{NH}_{3}$ produced in metabolic acidosis without an increase in enzyme activity. ${ }^{3}$ This may explain the prompt rise in $\mathrm{NH}_{3}$ excretion in acidotic dogs to maximal levels by the second day of ammonium chloride administration (Figure 1). Why, then, does enzyme adaptation occur in the

${ }^{3}$ Under the present experimental conditions the possibility has not been excluded that the increment in $\mathrm{NH}_{3}$ production could be very much greater when larger ammonium chloride loads are given. On two occasions we attempted to give a larger load of ammonium chloride, but the dogs vomited. Thus it was not possible to determine whether a much greater increment in $\mathrm{NH}_{3}$ production would be accompanied by an adaptive increase in glutaminase activity. 
rat? In the nonacidotic rat the derived in vivo glutaminase activity of cortex, medulla, and papilla has the capacity to split from glutamine only the same amount of $\mathrm{NH}_{3}$ as is excreted. Thus an increase in enzyme activity would be necessary to split the increased amount of $\mathrm{NH}_{3}$ excreted in metabolic acidosis. In the acidotic rat $\mathrm{NH}_{3}$ excretion increases slowly over a period of days (10), and this increase is accompanied by a parallel and progressive increase in glutaminase activity (10, 12).

The role of glutamate dehydrogenase in $\mathrm{NH}_{3}$ production. Ammonia excretion in acidotic dogs increases when certain amino acids other than glutamine are infused, particularly L-asparagine, Land $\mathrm{D}$-alanine, L-histidine, L-leucine, and glycine (5-8). However, L-amino acid oxidases have been reported to be virtually absent from dog kidney (26). We have confirmed this observation and have found in preliminary studies that asparaginase activity is extremely low. D-Alanine oxidase activity has been reported in kidney tissues by Krebs (27), but we found that the activity was low $(8.49 \mu$ moles per $g$ per minute $)$ and did not change during acidosis. The contribution of amino acids other than glutamine to $\mathrm{NH}_{3}$ production by the acidotic kidney is about 30 to $40 \%$ $(2,4)$. Since L-amino acid oxidases are apparently absent, the production of $\mathrm{NH}_{3}$ is likely to occur as a result of reactions through the amino transferase-glutamate dehydrogenase system, which is also linked with the $\alpha$-ketoacid-activated glutaminase (glutaminase II). These interrelationships are outlined in Figure 4.

Glutamine is desaminated to glutamate by glutaminase I. The glutamate formed can be desaminated by GDH. Glutamine is also desaminated and desamidated by glutaminase II via 2-oxoglutaramate. The cofactor is pyruvate, or 2-oxoglutarate or another 2-oxo acid. In Figure 4 two possibilities are considered:1) With pyruvate as cofactor, alanine, 2-oxoglutarate, and $\mathrm{NH}_{3}$ are the reaction products; pyruvate can be regenerated in the AlAT reaction, giving rise to glutamate. 2) With 2-oxoglutarate as cofactor, glutamate, 2-oxoglutarate, and $\mathrm{NH}_{3}$ are the reaction products; 2-oxoglutarate can feed back into the glutaminase II reaction. Glutamate is the most abundant amino acid in kidney tissue, constituting on a molar basis 39 to $49 \%$ of the free amino acid con- tent of the kidney cortex of the dog (3). Although glutamate is added to the venous blood of acidotic dogs, the amount added is small and is equivalent on a molar basis to only $4 \%$ of the glutamine extracted (3). This suggests that the glutamate generated in the several reactions outlined in Figure 4 is metabolized to 2-oxoglutarate and $\mathrm{NH}_{3}$ in the GDH reaction.

The amount of glutamate contributed by the amino acid pool through other amino acid amino transferase reactions is unknown. The GDH activity in vitro was about $75 \mu$ moles per $g$ per minute in the kidney cortex. For technical reasons this was measured in vitro at $\mathrm{pH} 7.4$ with $2.5 \mathrm{mM}$ 2-oxoglutarate as the substrate. In vivo $\mathrm{NH}_{3}$ is split from glutamate in the reaction, glutamate + $\mathrm{NAD} \rightarrow$ 2-oxoglutarate $+\mathrm{NADH}+\mathrm{NH}_{3}$. Experimentally we determine that the rate of desamination of glutamate at $\mathrm{pH} 7.1$ and at the in vivo concentration of $14.6 \mathrm{mM}$ (3) was $2 \%$ of the rate of the reverse reaction measured under the in vitro optimal conditions. The derived in vivo $\mathrm{GDH}$ activity in the kidney cortex was $1.50 \mu$ moles per $g$ per minute or $25 \mu$ moles per two kidney cortices per minute. Making similar assumptions the GDH of medulla and papilla would split only $4.4 \mu$ moles of glutamate per minute, giving rise to a total of $29.4 \mu$ moles of $\mathrm{NH}_{3}$ per two kidneys per minute. This is equivalent to $55 \%$ of the total $\mathrm{NH}_{3}$ excretion in the acidotic dogs, and to $42 \%$ of the $\mathrm{NH}_{3}$ production, and agrees closely with the conclusions of Van Slyke and Pitts, whose experimental evidence suggests that about 30 to $40 \%$ of the $\mathrm{NH}_{3}$ production by the acidotic dog kidney is contributed to by amino acids other than glutamine. Glutamate could also be the substrate for the synthesis of glutamine by glutamine synthase, but we found, as have others $(12,21)$, little or no glutamine synthase activity in the dog kidney.

Canessa-Fischer and colleagues (8) infused $\mathrm{L}$-alanine into the left renal artery of acidotic dogs; when the amino acid was infused at a rate of 300 $\mu$ moles per minute, they observed an increment of $\mathrm{NH}_{3}$ excreted by the two kidneys of about 30 $\mu$ moles per minute. Since L-alanine oxidase is virtually absent from the dog kidney, it is probable that the amino group of L-alanine is transferred to 2-oxoglutarate by AlAT. The derived in vivo AlAT activity is about $490 \mu$ moles per two kidneys per minute-sufficient to transfer the entire load 
of $\mathrm{NH}_{3}$. The increment of $\mathrm{NH}_{3}$ excreted would be derived from the desamination of glutamate by GDH (Figure 4). The limiting factor in determining the increment of $\mathrm{NH}_{3}$ excreted is therefore likely to be GDH. The GDH activity was calculated to be $29.4 \mu$ moles per two kidneys per minute, a figure agreeing closely with the observed increment in $\mathrm{NH}_{3}$ excretion in the infusion experiments. Pertinent to this is the observation that for all amino acids infused by Canessa-Fischer and associates, the increment in $\mathrm{NH}_{3}$ excretion did not exceed this value (8).

The derived data in the previous discussion must of course be interpreted with caution. That the assumptions underlying these derivations may be substantially correct is suggested by the fact that the derived data satisfactorily explain in a quantitative manner the following: 1) the production of ammonia from glutamine and from glutamate, 2) the different responses of the dog and the rat to experimental metabolic acidosis, and 3) the increment in $\mathrm{NH}_{3}$ excretion during infusion of amino acids other than glutamine.

The influence of metabolic acidosis on the other enzymes studied. The derived in vivo AspAT activity was about $2,000 \mu$ moles per two kidneys per minute and increased in metabolic acidosis. The reason for this increase is unexplained. The derived in vivo AlAT activity was about 490 $\mu$ moles per two kidneys per minute and did not change significantly in metabolic acidosis. Glutaminase and GDH are related directly to $\mathrm{NH}_{3}$ production, whereas AspAT and AlAT participate only indirectly. These aminotransferases must be considered in many aspects of amino acid metabolism, and their activity cannot be related quantitatively only to $\mathrm{NH}_{3}$ production.

The activity of two enzymes of the citric acid cycle, citrate synthase and malate dehydrogenase, did not increase in metabolic acidosis; nor was there any increase in $\mathrm{LDH}$ activity. These findings do not exclude the possibility that the activity of other enzymes of the cycle or of glycolysis may have changed in metabolic acidosis.

The role of carbonic anhydrase in the kidney. Although measured for technical reasons at $0^{\circ} \mathrm{C}$, CA activity was very high throughout the nephron. At $37^{\circ} \mathrm{C}$ the $\mathrm{CA}$ activity would probably be five times greater (28). CA activity of a similar order of magnitude has been found in the kidney of man
(29) and rat (30), and in erythrocytes (17), choroid plexus (31), and the salt gland of the herring gull (32). In the dog liver, by contrast, any activity present was less than the sensitivity of the method could detect. High CA activity occurs in those tissues concerned with $\mathrm{H}^{+}$excretion, $\mathrm{HCO}_{3}^{-}$transport, or both, but the activity measured in vitro is very much higher than expected. Nothing is known of intracellular regulation of CA activity, and no derivations for in vivo activity can be made.

\section{Summary}

1. Studies were designed to investigate quantitatively the enzymatic basis for ammonia production and hydrogen ion excretion in healthy dogs under normal metabolic conditions and during ammonium chloride-induced metabolic acidosis.

2. During the administration of $112 \mathrm{mEq}$ of ammonium chloride daily for 7 days, the urine $\mathrm{pH}$ fell from 6.85 to 5.47. The excretion of titratable acid increased from 3.6 to 17.4 mmoles per day, of ammonia from 20 to 78 mmoles per day, and of net hydrogen ion excretion from 16 to 93.5 mmoles per day.

3. Enzyme activities were measured in kidney and liver biopsies taken at the end of a 7-day control metabolic study and at the end of a 7-day period of ammonium chloride administration. In the kidney there was no change in the activity of glutaminase I and II, glutamate dehydrogenase, alanine amino transferase, $\mathrm{D}$-alanine oxidase, citrate synthase, carbonic anhydrase, lactate dehydrogenase, or malate dehydrogenase; aspartate amino transferase activity increased throughout the nephron in metabolic acidosis. In the liver there was no change in the activity of any of these enzymes, save for a slight increase in aspartate amino transferase activity.

4. From the in vitro data the total in vivo glutaminase I and II and glutamate dehydrogenase activities of the two dog kidneys were derived. It was calculated that in metabolic acidosis the glutaminases of the two kidneys would have split $46.9 \mu$ moles of glutamine per minute and that the glutamate dehydrogenase would have split 29.4 $\mu$ moles of glutamate per minute, in each case giving rise to equimolar amounts of ammonia. The ammonia production of the dogs was $70 \mu$ moles per 
minute. Thus sufficient glutaminase I and II and glutamate dehydrogenase activities appeared to be present to split all the ammonia produced in metabolic acidosis. About $60 \%$ of the ammonia would have derived from glutamine, the remainder from the other amino acids through the amino acid amino transferases and desamination of glutamate.

\section{Acknowledgments}

We wish to thank Dr. Steven G. Economou and Dr. Lionel J. Schewitz for operating on the dogs and Miss Antoinetta Arana, Miss Erica Enza, Mrs. Isabel Hamm, and Mr. Roy McClain for technical assistance. We are indebted to Mr. Mitchell Passovoy, Section of Biostatistics, Presbyterian-St. Luke's Hospital for statistical advice and assistance.

\section{References}

1. Sartorius, O. W., J. C. Roemmelt, and R. F. Pitts. The renal regulation of acid-base balance in man. IV. The nature of the renal compensations in ammonium chloride acidosis. J. clin. Invest. 1949, 28, 423.

2. Van Slyke, D. D., R. A. Philips, P. B. Hamilton, R. M. Archibald, P. H. Futcher, and A. Hiller. Glutamine as source material of urinary ammonia. J. biol. Chem. 1943, 150, 481.

3. Shalhoub, R., W. Webber, S. Glabman, M. CanessaFischer, J. Klein, J. DeHaas, and R. F. Pitts. Extraction of amino acids from and their addition to renal blood plasma. Amer. J. Physiol. 1963, 204, 181.

4. Pitts, R. F., J. DeHaas, and J. Klein. Relation of renal amino and amide nitrogen extraction to ammonia production. Amer. J. Physiol. 1963, 204, 187.

5. Bliss, S. Increased excretion of urinary ammonia in the dog following the intravenous injection of both natural and unnatural forms of certain amino acids. J. biol. Chem. 1941, 137, 217.

6. Lotspeich, W. D., and R. F. Pitts. The role of amino acids in the renal tubular secretion of ammonia. J. biol. Chem. 1947, 168, 611.

7. Kamin, H., and P. Handler. The metabolism of parenterally administered amino acids. III. Ammonia formation. J. biol. Chem. 1951, 193, 873.

8. Canessa-Fischer, M., R. Shalhoub, S. Glabman, J. DeHaas, and R. F. Pitts. Effects of infusions of ammonia, amides, and amino acids on excretion of ammonia. Amer. J. Physiol. 1963, 204, 192.

9. Davies, B. M. A., and J. Yudkin. Studies in biochemical adaptation. The origin of urinary ammonia as indicated by the effect of chronic acidosis and alkalosis on some renal enzymes in the rat. Biochem. J. 1952, 52, 407.
10. Rector, F. C., Jr., D. W. Seldin, and J. H. Copenhaver. The mechanism of ammonia excretion during ammonium chloride acidosis. J. clin. Invest. 1955, 34, 20.

11. Richterich-Von Baerle, R., L. Goldstein, and E. H. Dearborn. Relation of ammonia excretion to urine $\mathrm{pH}$ in the guinea pig. Science 1956, 124, 74.

12. Rector, F. C., and J. Orloff. The effect of the administration of sodium bicarbonate and ammonium chloride on the excretion and production of ammonia. The absence of alterations in the activity of renal ammonia-producing enzymes in the dog. J. clin. Invest. 1959, 38, 366.

13. Bloom, F. Pathology of the Dog and Cat. The Genitourinary System, with Clinical Considerations. Evanston, American Veterinary Publications, 1954, pp. 73-101.

14. Bonting, S. L., V. E. Pollak, R. C. Muehrcke, and R. M. Kark. Quantitative histochemistry of the nephron. II. Alkaline phosphatase activity in man and other species. J. clin. Invest. 1960, 39, 1372.

15. Bonting, S. L., and B. R. Mayron. Construction, calibration, and use of a modified quartz fiber "fishpole" ultramicrobalance. Microchem. J. 1961, 5, 31.

16. Bonting, S. L., V. E. Pollak, R. C. Muehrcke, and R. M. Kark. Quantitative histochemistry of the nephron. III. Lactic dehydrogenase activity in man and other species. J. clin. Invest. 1960, 39, 1381.

17. Mattenheimer, $H$., and $H$. DeBruin. An ultramicro method for determination of carbonic anhydrase activity. Analyt. Biochem. 1962, 4, 222.

18. Mattenheimer, H., and H. DeBruin. Glutaminases. An ultramicro method for the determination of glutaminase activity, and a reinvestigation of optimum assay conditions in the kidney of man, dog and rat. Enzym. Biol. Clin. (Basel) 1964, 4, 65.

19. Mattenheimer, H., V. E. Pollak, and H. DeBruin. Quantitative histochemistry of the nephron. IX. Distribution and activity of various enzymes in the kidney of the dog. Enzym. Biol. Clin. (Basel) 1964, 4, 107.

20. Report of the Commission on Enzymes of the International Union of Biochemistry. I.U.B. Symposium Series. Oxford, Pergamon, 1961, vol. 20.

21. Richterich, R., and L. Goldstein. Distribution of glutamine metabolizing enzymes and production of urinary ammonia in the mammalian kidney. Amer. J. Physiol. 1958, 195, 316.

22. Owen, E. E., and R. R. Robinson. Amino acid extraction and ammonia metabolism by the human kidney during the prolonged administration of ammonium chloride. J. clin. Invest. 1963, 42, 263.

23. Lowy, R., F. Decloitre, and L. Brigant. Méthode de fractionnement et de dosage des composés phosphorés tissulaires. Enzym. Biol. Clin. (Basel) 1964, 4, 39. 
24. Robin, E. D. Of men and mitochondria-intracellular and subcellular acid-base relations. New Engl. J. Med. 1961, 265, 780.

25. Smith, H. W. The Kidney. Structure and Function in Health and Disease. New York, Oxford, 1951, p. 564.

26. Blanchard, M., D. E. Green, V. Nocito, and S. Ratner. L-Amino acid oxidase of animal tissue. J. biol. Chem. 1944, 155, 421.

27. Krebs, H. A. Metabolism of amino-acids. III. Deamination of amino-acids. Biochem. J. 1935, 29, 1620.

28. Meldrum, N. U., and F. J. W. Roughton. Carbonic anhydrase. Its preparation and properties. J. Physiol. (Lond.) 1933, 80, 113.
29. Mattenheimer, H., V. E. Pollak, R. C. Muehrcke, and R. M. Kark. Quantitative Enzymverteilungsmuster in Nephron. Verh. dtsch. Ges. inn. Med. 1964, 70, 579.

30. Wacker, G. R., H. S. Zarkowsky, and H. B. Burch. Changes in kidney enzymes of rats after birth. Amer. J. Physiol. 1961, 200, 367.

31. Vates, T. S., Jr., S. L. Bonting, and W. W. Oppelt. $\mathrm{Na}-\mathrm{K}$ activated adenosine triphosphatase formation of cerebrospinal fluid in the cat. Amer. J. Physiol. 1964, 206, 1165.

32. Bonting, S. L., L. L. Caravaggio, M. R. Canaday, and N. M. Hawkins. Studies on sodium-potassiumactivated adenosinetriphosphatase. XI. The salt gland of the herring gull. Arch. Biochem. 1964, 106, 49.

\section{ANNOUNCEMENT OF MEETINGS}

The American Federation for Clinical Research will hold its Twentysecond Annual Meeting in Atlantic City, N. J., at the Casino Theater on the Steel Pier on Sunday, May 2, 1965, at 9:00 a.m. Joint sectional meetings with The Américan Society for Clinical Investigation will be held on Sunday afternoon at Chalfonte-Haddon Hall, and additional meetings sponsored by The American Federation for Clinical Research will be held on Sunday evening.

The American Society for Clinical Investigation, Inc., will hold its Fifty-seventh Annual Meeting in Atlantic City, N. J., on Monday, May 3, at 9:00 a.m., at the Casino Theater on the Steel Pier, and will join The American Federation for Clinical Research in simultaneous sectional meetings on Sunday afternoon, May 2, in Chalfonte-Haddon Hall.

The Association of American Physicians will hold its Seventy-eighth Annual Meeting in Atlantic City, N. J., at the Casino Theater on the Steel Pier on Tuesday, May 4, at 9:30 a.m., and in the Carolina Room, Chalfonte-Haddon Hall, on Wednesday, May 5, at 9:30 a.m. 